Sains Malaysiana 51(1)(2022): 15-26

http://doi.org/10.17576/jsm-2022-5101-02

\title{
Morphometric Variation among 28 Sub-populations of Barbodes binotatus in Indonesia
}

(Variasi Morfometri dalam kalangan 28 Sub-Populasi Barbodes binotatus di Indonesia)

\author{
Septiana Sri astuti, Anik Martinah Hariati, Wahyu Endra Kusuma \& Dewa Gede RaKa WiadnyA*
}

\begin{abstract}
Morphological variability-based truss morphometry analysis is often used to identify fish population, morphometric asymmetry, and evolutionary changes of fishes. This study aims to analyze the level of symmetry and asymmetry of Barbodes binotatus from several sampling areas in terms of geographic distribution variability in Indonesia, such as Java, Bali, Nusa Tenggara, Sumatera, Kalimantan and Sulawesi. A total of 845 samples were collected from 28 sampling areas. Digital imaging and landmark points were analyzed using the tpsDig.2 program. The parameters including standard landmarks, truss morphometry and geometric-morphometric analysis were completed using SAGE software in order to identify the symmetry-asymmetry level of fishes from each location. Results showed a highly asymmetry level $(P<0.0001)$ in procrustes ANOVA with three factors analyzed: Individual analysis, side identification, and interactions of individual and side. The asymmetry levels of $\mathrm{B}$. binotatus were varied within areas, which recorded at $65.31 \%$ for Java Island, 50.16\% for Nusa Tenggara, 67.12\% for Bali, 67.12\% for Sumatera, 30.15\% for Kalimantan, and $30.17 \%$ for Sulawesi. The asymmetry level of B. binotatus in four major regions (Java, Nusa Tenggara, Bali, and Sumatra) was significantly higher $(P<0.0001)$, while other areas in Kalimantan and Sulawesi tend to be lower than others $(P>0.0001)$. Further research with a genetic approach is needed to identify genetic populations and prove the existence of genetic factors that affect the level of asymmetry in individual body shape.
\end{abstract}

Keywords: Barbodes binotatus; fluctuating asymmetry; morphometric asymmetry

\section{ABSTRAK}

Analisis morfometri kekuda berasaskan kebolehubahan morfologi sering digunakan untuk mengenal pasti populasi ikan, asimetri morfometri dan perubahan evolusi ikan. Kajian ini bertujuan untuk menganalisis tahap simetri dan asimetri Barbodes binotatus daripada beberapa kawasan persampelan daripada segi kebolehubahan taburan geografi di Indonesia, seperti Jawa, Bali, Nusa Tenggara, Sumatera, Kalimantan dan Sulawesi. Sebanyak 845 sampel telah dikumpul dari 28 kawasan persampelan. Pengimejan digital dan titik mercu tanda dianalisis menggunakan program tpsDig.2. Parameter termasuk tanda tempat piawai, morfometri kekuda dan analisis geometri-morfometri telah dilengkapkan menggunakan perisian SAGE untuk mengenal pasti tahap simetri-asimetri ikan dari setiap lokasi. Keputusan menunjukkan tahap asimetri tinggi $(P<0.0001)$ dalam procrusts ANOVA dengan tiga faktor dianalisis: analisis individu, pengenalan sisi, dan interaksi individu dan sisi. Tahap asimetri B. binotatus adalah berbeza-beza antara kawasan dengan 65.31\% untuk Pulau Jawa, 50.16\% untuk Nusa Tenggara, 67.12\% untuk Bali, 67.12\% untuk Sumatera, 30.15\% untuk Kalimantan dan 30.17\% untuk Sulawesi. Tahap asimetri B. binotatus di empat wilayah utama (Jawa, Nusa Tenggara, Bali dan Sumatera) adalah lebih tinggi secara signifikan $(P<0.0001)$, manakala kawasan lain di Kalimantan dan Sulawesi cenderung lebih rendah daripada yang lain ( $P>0.0001)$. Kajian lanjut dengan pendekatan genetik diperlukan untuk mengenal pasti populasi genetik dan membuktikan kewujudan faktor genetik yang mempengaruhi tahap asimetri dalam bentuk badan individu.

Kata kunci: Asimetri morfometrik; asimetri turun naik; Barbodes binotatus

\section{INTRODUCTION}

Fish identification based on phenotypic characteristics, morphology, and morphometric analysis has been widely used in several studies (Poulet et al. 2005). Morphological analysis and fish identification were carried out based on several aspects including body shape, number of fins, geometric shape, and meristic character which are the most 
basic points in determining fish species (Cadrin 2000; Farinordin et al. 2017; Ibanez et al. 2007). Morphological and morphometric character are closely related to the existence of influential external factors such as changes in habitat and geographical conditions of each distribution area (Johnson et al. 2004; Leamy \& Klingenberg 2005). The development of organisms in different environmental factors and geographic boundaries can affect the differences in the development of bilateral characters and fluctuating asymmetry (Almeida et al. 2008; Hata et al. 2013; Wedekind \& Muller 2004). The fluctuating asymmetry pattern is a homeostatic control that can be disturbed for several reasons, such as anthropogenic stress and environmental changes (Bergstrom \& Reimchen 2005; Bergstrom et al. 2010). The degree value of asymmetry level will be directly proportional to the presence of influencing factors such as external environmental pressure and internal factors that affect the development process such as inbreeding activity (Bergstrom \& Reimchen 2002; Daloso 2014; Iguchi et al. 2005; Presilda et al. 2016).

Several factors regarding habitat conditions, environmental stresses, and the presence of geographic differences also have an impact on individual mortality rates, phenotypic characteristics, and the survival rate of organisms (Muallil et al. 2014; Presilda et al. 2016). It is important to analyze the factors that drive the variability of organisms and patterns of biological adaptation in terms of geographical distribution and environmental conditions (Ducos \& Tabugo 2015; Natividad et al. 2015).

Barbodes binotatus (Valenciennes 1842) is a freshwater fish of the family Cyprinidae, with several synonym names in scientific literature such as Puntius binotatus, Systomus binotatus, Capoeta binotata, and Barbus maculatus (Jenkins et al. 2015; Kottelat 2013). Barbodes binotatus is an endemic fish from Indonesia, native species from Southeast Asia, and widespread in Laos, Vietnam, Cambodia, Myanmar, Brunei, Malaysia, Philippines, Thailand, and Indonesia (Jenkins et al. 2015). B. binotatus is one of the important aquatic organisms at the second trophic level (Isa et al. 2010; Zakeyudin et al. 2012). This fish has economic value among local communities in Asia, especially in Indonesia (Lim et al. 2013). Further research and utilization of this species should be focused on its natural populations with several major studies on distribution patterns and morphological features (Dar et al. 2012). B. binotatus has been distinguished from other species by its phenotypic characteristics with four barbells, silvery gray body color with a darker point, a rounded body pattern at the base of the caudal peduncle in large specimens, and a broad muzzle tip. B. binotatus is known as a benthopelagic species that can live in a pH range of $6.0-6.5$ and temperatures of $24-26{ }^{\circ} \mathrm{C}$ in tropical countries. B. binotatus is a plankton feeder and has been used as a bio-indicator in assessing the quality and status of freshwater resources (Baumgartner 2005; Zakeyudin et al. 2012).

The focus of this study is specifically related to the impact of geographic distribution on the presence of fluctuating asymmetry (FA) in fish population (Ducos \& Tabugo 2015). Several reports regarding the emergence of FA in individuals occur due to external factors in their habitat. Other studies report that environmental stress and geographic distribution can increase FA, but there are few studies that clearly demonstrate this effect (Kihslinger et al. 2006; Kocour et al. 2007). The relationship between FA and geographic conditions has provided evidence that environmental stresses also have an impact on individual phylogenetic relationships (Fessehaye et al. 2007). Sampling locations with different geographic areas and environments can affect the morphological variability of species in the population (Kark 2001). This relationship suggests that rivers and fish habitats with different conditions also contribute to the morphological characters and levels of asymmetry that occur in different populations.

This study aims to determine the possible influence of geographic areas on the appearance of fluctuating asymmetry in a population. These results will be used to evaluate the morphological variability of all species collections. Thus, the results of this study will be significant due to the ongoing development research and to develop the potential of $B$. binotatus as a species candidate in aquaculture.

\section{MATERIALS AND METHOdS}

\section{FISH COLLECTION, LANDMARK SELECTION AND DIGITATION}

Specimens were collected from June 2019 to June 2020 at 28 different locations from Java Island (18 sub populations), Bali (2 sub populations), Nusa Tenggara (2 sub populations), Sumatera (2 sub populations), Kalimantan (2 sub populations) and Sulawesi (2 sub populations). The sampling locations in Java consisted of 18 locations (Pamekasan, Bondowoso, Lumajang, Jember, Banyuwangi, Situbondo, Malang, Blitar, Semarang, Tuban, Yogyakarta, Sleman, Cirebon, Cilacap, Nusa Kambangan, Bogor, Banten and Bandung), Bali (Bedugul and Jembrana), Sumatra (Jambi and Bengkulu), Nusa Tenggara (Lombok and Sumbawa), Kalimantan (Samarinda and Banjarmasin), and Sulawesi (Majene and Malo). A total of 845 specimens captured with various types of fishing gear including nets and trap equipment. 
Fish specimens were stored in $96 \%$ alcohol to maintain sample quality. All specimens from each sampling location were registered at Depository Ichtyologicum Brawijaya, University of Brawijaya (J1. Veteran Ketawanggede, Lowokwaru, Malang, East Java). Specimens were labeled from each location. Information on the label includes the date of sampling, name of the collector, method of collection, location, coordinates, and geographic reference. Labels were written in permanent black ink on $100 \%$ linen paper.
Morphological documentation was carried out by digital marking using Canon EOS 650D Japan (18 megapixels). Morphological images were converted to TPS file format using tpsUtil. The selection of landmark point was carried out using tpsDig2 v.2 (Rohlf 2004). A total of fifteen anatomical landmark points (Table 1) were used to digitize morphometric character of $B$. binotatus (Figure 1). Population distribution maps and sampling areas were carried out at 28 locations (Figure 2).

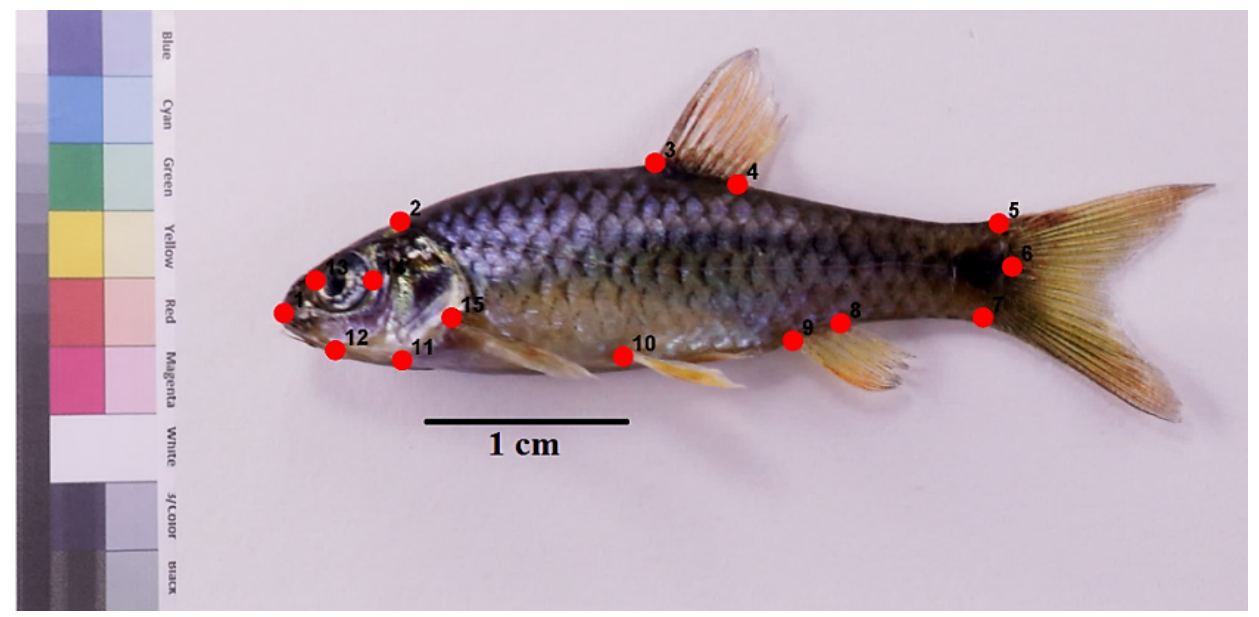

FIGURE 1. Landmark points of B. binotatus

(Source: Astuti et al. 2020)

\section{Sampling Area of B. binotatus in Indonesia}

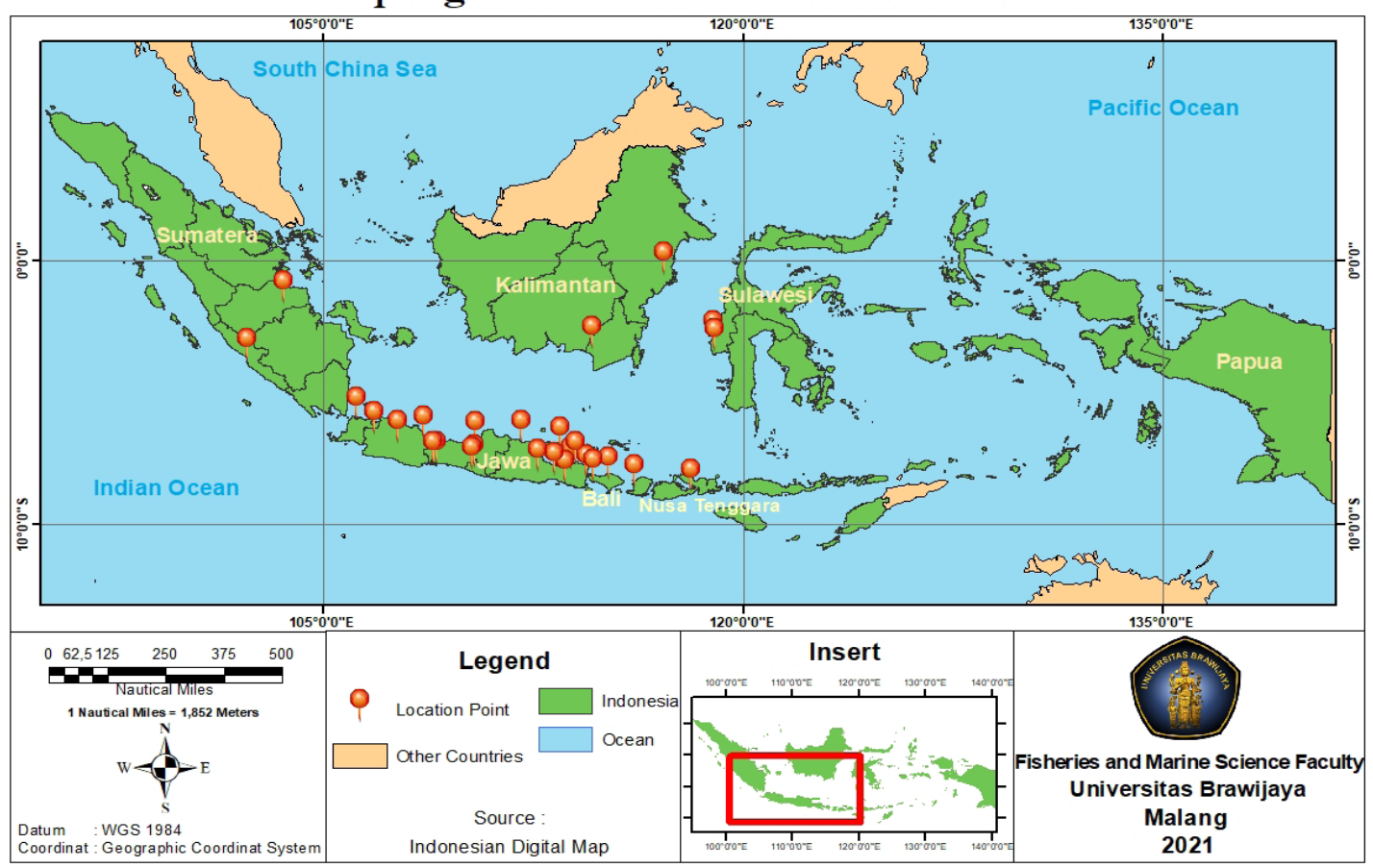

FIGURE 2. Sampling area from the 28 sub-populations of Barbodes binotatus. The sampling locations in Java consisted of 18 locations (Pamekasan, Bondowoso, Lumajang, Jember, Banyuwangi, Situbondo, Malang, Blitar, Semarang, Tuban, Yogyakarta, Sleman, Cirebon, Cilacap, Nusa Kambangan, Bogor, Banten and Bandung), Bali (Bedugul and Jembrana), Sumatra (Jambi and Bengkulu), Nusa Tenggara (Lombok and Sumbawa), Kalimantan (Samarinda and 
SHAPE ANALYSIS

Body shape analysis and specimen digitization were carried out in three replications using the tpsDig2 application. The coordinate data were subjected to Symmetry and Asymmetry in Geometric Data version 1.04 software (Marquez 2007) to obtain the principal components of individual symmetry which denotes by deformation grid (Natividad et al. 2015). The Procrustes ANOVA test was conducted to determine the level of asymmetry for each individual from the three factors considered including identification of individual shape, identification of body sides, and interactions between individuals and sides of the body. This level of significance was confirmed with P-value $<0.0001$ which determines the degree of asymmetry in the population.

TABLE 1. Landmark point and digitation

\begin{tabular}{ll}
\hline Landmark Point & Location \\
\hline 1 & Snout tip \\
2 & Posterior end of nuchal spine \\
3 & Anterior insertion of dorsal fin \\
4 & Posterior insertion of dorsal fin \\
5 & Dorsal insertion of caudal fin \\
6 & Midpoint of lateral line \\
7 & Ventral insertion of caudal fin \\
8 & Posterior insertion of anal fin \\
9 & Anterior insertion of anal fin \\
10 & Dorsal base of pelvic fin \\
11 & Ventral end of lower jaw articulation \\
12 & Posterior end of the premaxilla \\
13 & Anterior margin through midline of orbit \\
14 & Posterior margin through midline of orbit \\
15 & Dorsal base of pectoral fin \\
\hline
\end{tabular}

(Source: Cabuga et al. 2017)

The percentage (\%) of FA were acquired and compared for all species. Morphometric analysis was performed using SAGE software (Symmetry and Asymmetry of Geometric Data, ver. 1.04) with a protocol that identifies specimen numbers with labels and ID tags, and all points were stored in a data file (notepad) as specimens identified in the format 'txt'. The landmark points on each side of the individual body were used to match the symmetry with the values ' 0 ' as the right side and ' 1 ' as the left side in three pre-created replicates and saved as '.txt' file. All files with the '.tps' format in the tpsDig application were analyzed with three replications and 99 permutations. The subsequent results of the application were analyzed using the SAGE program to measure the level of symmetry and asymmetry of individuals based on body shape. The results were represented by P-values to determine the comparative effects of individuals and side bodies which illustrates the fluctuating asymmetric patterns in the data.

\section{RESULTS AND DISCUSSION}

MORPHOLOGICAL VARIABILITY AND MORPHOMETRIC ANALYSIS

The current research reported morphological variability of $B$. binotatus from different geographic distributions 
(Tables $2 \& 3$ ). There are nine parameters compared with Standard Length (SL) of the body shape. Morphometric measurements were compared with standard lengths to obtain truss morphometry values as the main data for determining the comparison between landmark points to produce standard symmetrical patterns and asymmetric analysis of individual body shapes. Within the same species, differences in body shape are an important factor in differentiating homogeneous groups of fish. In general, the morphometric approach shows that the comparison of morphometric characters can be used to differentiate populations based on habitat conditions and geographic areas as determining factors. The results of the morphometric analysis depend on specific measurements selected from several characters. Morphometric distances can be measured and calculated from the results of the marking of 'landmark morphometry'. Homologous landmark morphometry represents a similar development among specimens. The selection of measurement points describes the difference in the average length ratio of the individual shape characters (Dwivedi \& Dubey 2012).

Morphometric differences within a species are generally associated with geographic isolation due to the interactive effects of environment, selection, and genetics on individual ontogenies (Poulet et al. 2005). Morphometric characteristics usually indicate the ontogenetic changes associated with allometric growth (Robinson \& Parsons 2002). These ontogenetic changes in body shape can occur rapidly at major life-history stages, such as metamorphosis from larvae to juvenile body shape, and sexual maturation (Swain et al. 2005). Differences in morphological and morphometric variations cannot be separated from habitat conditions, including intraspecific differences (Hendry et al. 2003; McKinnon et al. 2004).

Similar studies have shown that morphological differences occur in populations of $B$. binotatus which occupy different habitats (Cabuga et al. 2017; Hernando et al. 2016; Lutterschmidt et al. 2016). Environmental conditions and anthropogenic stressors can have a negative impact on the environmental quality of aquatic ecosystems (Seixas et al. 2016). The results showed that the highest fluctuating in morphometric characters was found in the ratio between standard length and total length. Morphometric variations in individual shapes may occur due to habitat conditions and river flows that provide adaptation patterns in order to survive in these aquatic conditions. This is also supported by research which shows that morphological differences between fish populations in reservoirs and rivers can have a direct impact on their growth (Langerhans \& Reznick 2010). This adaptive response that occurs in different selections may be related to genetic differentiation within the population (Langerhans 2008).

TABLE 2. Morphological variability of B. binotatus from Java, Bali, Nusa Tenggara, Sumatera Kalimantan, and Sulawesi

\begin{tabular}{lcccccc}
\hline & $\begin{array}{c}\text { Java Island } \\
\text { Characteristic }\end{array}$ & $\begin{array}{c}\text { Kalimantan } \\
(\mathrm{N}=700)\end{array}$ & $\begin{array}{c}\text { Sulawesi } \\
(\mathrm{N}=30)\end{array}$ & $\begin{array}{c}\text { Bali } \\
(\mathrm{N}=30)\end{array}$ & $\begin{array}{c}\text { Nusa Tenggara } \\
(\mathrm{N}=50)\end{array}$ & $\begin{array}{c}\text { Sumatera } \\
(\mathrm{N}=30)\end{array}$ \\
\cline { 2 - 6 }$(\mathrm{N}=30)$
\end{tabular}




\section{FLUCTUATING ASYMMETRY (FA)}

The fluctuation values are defined from the results of Procrustes ANOVA calculation to describe the morphometric variations of individual shapes that occur in several samples. The results showed a fluctuating asymmetry in the ratio between individual and the shape of the body which influenced the morphometric variations in the population of Java, Sumatra, Kalimantan, Bali, Nusa Tenggara, and Sulawesi. The highest variance in FA represents the highest morphometric asymmetry in the population. The variance of FA implies that geographical distributions and environmental conditions have an impact on morphometric asymmetry in the population (Pana et al. 2015). Another possibility that supports the highest fluctuation in the level of asymmetry is due to the high inbreeding activity in each population (Kark et al. 2004; Mazzi et al. 2002; Trokovic et al 2014). In addition, environmental and species boundaries encourage asymmetry in individuals due to environmental stress factors that occur in a population (Sotola et al. 2019). Morphometric asymmetry of $B$. binotatus was analyzed from all locations in Java, Bali, Sumatera, Kalimantan, Nusa Tenggara, and Sulawesi.

These results represent significant (high) and insignificant (low) levels of asymmetry in B. binotatus. This calculation is obtained from the morphometric characteristics and comparison of landmark points (Table 3). This degree of asymmetry has been found in the calculated factors (individual and side identifications). The fluctuating asymmetry of the population is influenced by shifting of landmark points. This pattern emerged from the comparison of truss morphometry and PCA analysis. The results showed fluctuating asymmetry in individuals compared between landmark points and truss morphometry had varying values in each population.

TABLE 3. Procrustes ANOVA on the body shape of B. binotatus

\begin{tabular}{|c|c|c|c|c|c|c|}
\hline Site & Factors & SS & DF & MS & $\mathrm{F}$ & P-Value \\
\hline \multirow[t]{4}{*}{1} & Java Island & & & & & \\
\hline & Individuals & 0.2119 & 2430 & 0.0039 & 1.9077 & $0.0001 *$ \\
\hline & Sides & 0.0148 & 11 & 0 & 1.7849 & $0.0001 *$ \\
\hline & Individual $\times$ Sides & 0.0785 & 2430 & 0 & 0 & $0.0001^{* *}$ \\
\hline \multirow[t]{4}{*}{2} & Nusa Tenggara & & & & & \\
\hline & Individuals & 0.4115 & 2610 & 0.0017 & 2.1716 & $0.0001 *$ \\
\hline & Sides & 0.0382 & 11 & 0 & 1.1426 & $0.0001 *$ \\
\hline & Individual $\times$ Sides & 0.0928 & 2610 & 0 & 0 & $0.0001^{* *}$ \\
\hline \multirow[t]{4}{*}{3} & Sumatera & & & & & \\
\hline & Individuals & 0.5912 & 2980 & 0.0011 & 1.2776 & $0.0001 *$ \\
\hline & Sides & 0.0165 & 11 & 0 & 1.4256 & $0.0001 *$ \\
\hline & Individual $\times$ Sides & 0.0879 & 2980 & 0 & 0 & $0.0001^{* *}$ \\
\hline \multirow[t]{4}{*}{4} & Bali & & & & & \\
\hline & Individuals & 0.1072 & 2460 & 0.0007 & 1.7126 & $0.0001 *$ \\
\hline & Sides & 0.0154 & 11 & 0 & 1.2246 & $0.0001 *$ \\
\hline & Individual $\times$ Sides & 0.0856 & 2460 & 0 & 0 & $0.0001^{* *}$ \\
\hline \multirow[t]{4}{*}{5.} & Kalimantan & & & & & \\
\hline & Individuals & 0.1025 & 1410 & 0.05 & 1.5211 & $0.05^{\mathrm{ns}}$ \\
\hline & Sides & 0.0112 & 11 & 0 & 1.2098 & $0.05^{\mathrm{ns}}$ \\
\hline & Individual $\times$ Sides & 0.0553 & 1410 & 0 & 0 & $0.05^{\mathrm{ns}}$ \\
\hline \multirow[t]{4}{*}{6} & Sulawesi & & & & & \\
\hline & Individuals & 0.0098 & 1780 & 0.01 & 1.7134 & $0.01^{\mathrm{ns}}$ \\
\hline & Sides & 0.0104 & 11 & 0 & 1.2283 & $0.01^{\mathrm{ns}}$ \\
\hline & Individual $\times$ Sides & 0.0516 & 1780 & 0 & 0 & $0.01^{\mathrm{ns}}$ \\
\hline
\end{tabular}


The highest asymmetry values were generated from Java, Bali, Sumatra, and Nusa Tenggara $(\mathrm{P}<0.0001)$, whereas the asymmetry level of B. binotatus from Kalimantan and Sulawesi were not significantly high $(\mathrm{P}>0.001)$. The FA component in fish populations associated with stress conditions in the environment from various types of habitats and geographic areas (Lecera et al. 2015). As a result, ecosystems with different characteristics of geographic areas will eventually lead to morphological variations that affect the growth and development of organisms (Bonada \& Williams 2002). This is consistent with several studies which prove that populations with large FA values are due to the adaptation pattern of high stressors in their habitat (Hermita et al. 2013). The difference in the level of asymmetry is one of the characteristics of a population that tends to be unable to adapt and protect itself from changing environmental conditions (Natividad et al. 2015). The FA score with the lowest percentage relates to its stability and ability to adapt in various environmental conditions that support the population to thrive (Bonada \& Williams 2002; Ducos \& Tabugo 2015).

Morphometric analysis and fluctuating asymmetry are often used to determine the effect of environmental disturbances from the comparison of symmetrical deviations and bilateral structures on the body shape of the species (Savriama et al. 2012). Asymmetry deviations occur due to the inability to withstand disturbances from environmental endogenous conditions during their development (Hermita et al. 2013). This deviation is associated with the presence of asymmetric fluctuation (FA) in non-directional deviations and serves as a potential indicator to describe the differences in body shape of an organism (Daloso 2014; Dorado et al. 2012) FA is an efficient method in providing important information regarding the variability of organism development through geometric analysis (Trono et al. 2015). The results of geometric analysis include differences in morphological, morphometric, and meristic features that support the asymmetry results in different species (Polly 2019). Other studies have theorized that environment and genetics are closely related to fluctuating asymmetric values, as well as the development of organisms in their habitats (Bergstrom \& Reimchen 2003). These two things are closely related because the body shape of an organism is the result of its response to environmental conditions, and the genotype of an organism will change along with different environmental conditions (Iwamoto et al. 2012).
CORRELATION BETWEEN GEOMETRIC-MORPHOMETRIC AND FLUCTUATING ASYMMETRY

The correlation between the geometry-morphometry and the fluctuating asymmetry of the body shape are generated through the affected landmarks. The results of FA analysis from Java Island have a large asymmetry values in Principal Component 1 (PC 1) with affected landmarks 1, 3, 4, 5, 7, 11 and 12 of all populations (Table 4). The comparison of FA from Nusa Tenggara shows high values of asymmetry level in affected landmark $1,2,4,5,6,7,8,10,11$, and 12. Affected landmark of the population from Sumatera is also described with the highest score in landmark positions $1,4,7,9,11,12$, and 13. Another result shows the affected landmark of the population from Bali with the highest score in landmark points $1,2,3,7,8,9,11$, and 12 . Different results were obtained from the populations of Kalimantan and Sulawesi which had less shifting of landmark points which showed low fluctuating asymmetry at the landmark points 1 , 2, 4, 5 and 1, 2, 3, 4, 5. These affected landmarks are displayed in a deformation grid that represents the degree of asymmetry in the shape of the body.

The mechanism of asymmetric fluctuation is able to provide an overview of variations in morphological characteristics as a result of several influencing factors (Swaddle 2003). This mechanism provides basic data for geometric analysis as an important instrument because of its ability to show changes in the body shape of organisms (Jumawan et al. 2016). The principal component (PC) of the affected landmark is a value that describes the fluctuating pattern of asymmetry and all components are calculated using the symmetry and asymmetry scores of the sample.

In this study, four main components (PC) were considered as the result of morphometric analysis in all samples from the entire population. The highest PC score determines the affected landmark in the body shape. The asymmetric pattern in the morphometric shape is described in the results of geometric analysis (Figure 3). Affected landmarks are visualized in a deformation grid and histogram values to illustrate the asymmetric pattern in the body shape of the organism. The points on the landmark represent different fluctuations in the affected parts.

The cumulative variation of the morphometric analysis is represented in the four PC in the sample. The highest variation that describes the morphometric asymmetry can be seen from the PC value and the visualization of the grid deformation. Fluctuating asymmetry with the highest scores can be found in 
landmark areas: 1 (snout tip), 2 (posterior end of nuchal spine), 3 (anterior insertion of dorsal fin), 4 (posterior dorsal fin insertion), 5 (dorsal insertion of caudal fin), 6 (midpoint or lateral line), 10 (dorsal base of pelvic fin), 11 (ventral end of lower jaw articulation) and 12 (posterior end of the premaxilla). The illustration of the fluctuating asymmetry is summarized using the results of PC1 and
PC2 as the highest values in all components in the system. The highest FA level in the bilateral morphology of fish has the closest assumption that species are under pressure which influences them to maintain their developmental homeostasis which greatly affects the growth and development patterns of fish, resulting in fluctuating asymmetry in the body shape of the species (Presilda et al. 2016).

TABLE 4. Fluctuating asymmetry - geometric morphometric analysis

\begin{tabular}{|c|c|c|c|}
\hline Site & Principal component & Fluctuating asymmetry (\%) & Affected landmark \\
\hline \multirow[t]{6}{*}{1} & Java Island & & \\
\hline & PC-1 & 40.25 & $1,3,4,5,6,7,11,12$ \\
\hline & PC-2 & 10.71 & $2,4,5,7$ \\
\hline & PC-3 & 9.87 & $5,7,11$ \\
\hline & PC-4 & 4.48 & $8,10,12$ \\
\hline & Total & 65.31 & \\
\hline \multirow[t]{6}{*}{2} & Nusa Tenggara & & \\
\hline & PC-1 & 32.48 & $1,2,4,5,6,7,8,10,11,12$ \\
\hline & PC-2 & 9.50 & $1,2,5,7$ \\
\hline & PC-3 & 7.01 & $7,11,13$ \\
\hline & PC-4 & 1.27 & 5,6 \\
\hline & Total & 50.16 & \\
\hline \multirow[t]{6}{*}{3} & Sumatera & & \\
\hline & PC-1 & 40.34 & $1,4,7,9,11,12,13$ \\
\hline & PC-2 & 11.18 & $1,3,6,8,10,11$ \\
\hline & PC-3 & 4. 11 & $2,3,4,9$ \\
\hline & PC-4 & 3.03 & $1,4,8$ \\
\hline & Total & 58.66 & \\
\hline \multirow[t]{6}{*}{4} & Bali & & \\
\hline & PC-1 & 52.21 & $1,2,3,7,8,9,11,12$ \\
\hline & PC-2 & 7.91 & $1,2,5,7,10$ \\
\hline & PC-3 & 5.25 & $2,6,8$ \\
\hline & PC-4 & 1.75 & 4,9 \\
\hline & Total & 67.12 & \\
\hline \multirow[t]{6}{*}{5} & Sulawesi & & \\
\hline & PC-1 & 20.05 & $1,2,4,5$ \\
\hline & PC-2 & 6.70 & $3,6,7,8$ \\
\hline & PC-3 & 2.11 & 9,10 \\
\hline & PC-4 & 2.31 & 11 \\
\hline & Total & 30.17 & \\
\hline \multirow[t]{6}{*}{6} & Kalimantan & & \\
\hline & PC-1 & 15.87 & $1,2,3,4,5$ \\
\hline & PC-2 & 7.08 & $4,5,9$ \\
\hline & PC-3 & 5.21 & $5,9,10$ \\
\hline & PC-4 & 1.99 & 10,11 \\
\hline & Total & 30.15 & \\
\hline
\end{tabular}



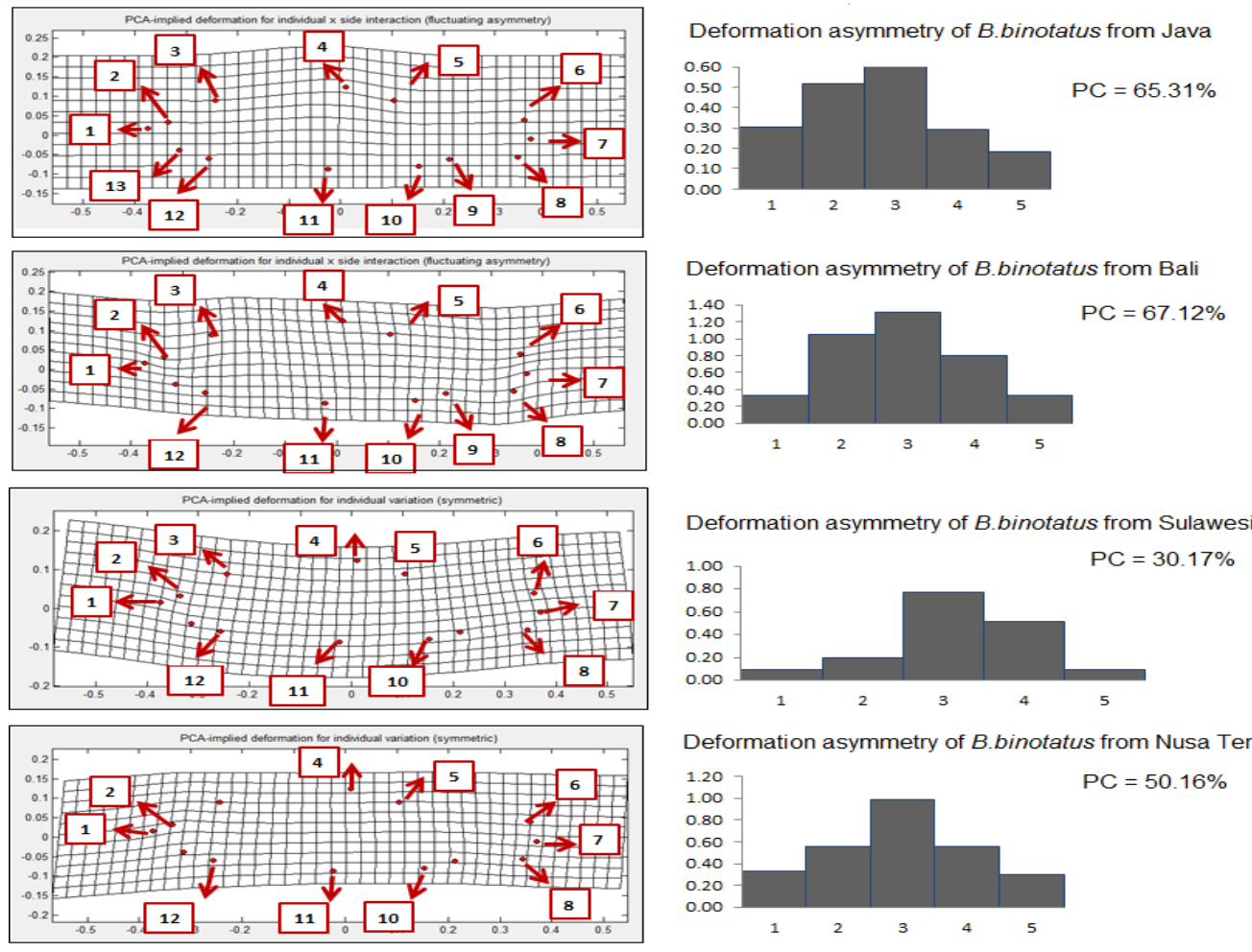

Deformation asymmetry of B.binotatus from Nusa Tenggara
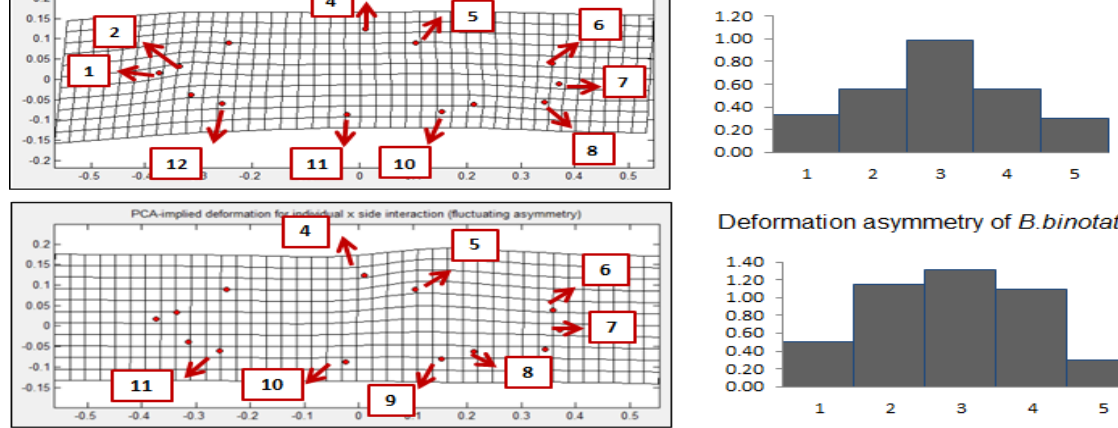

Deformation asymmetry of B.binotatus from Sumatera
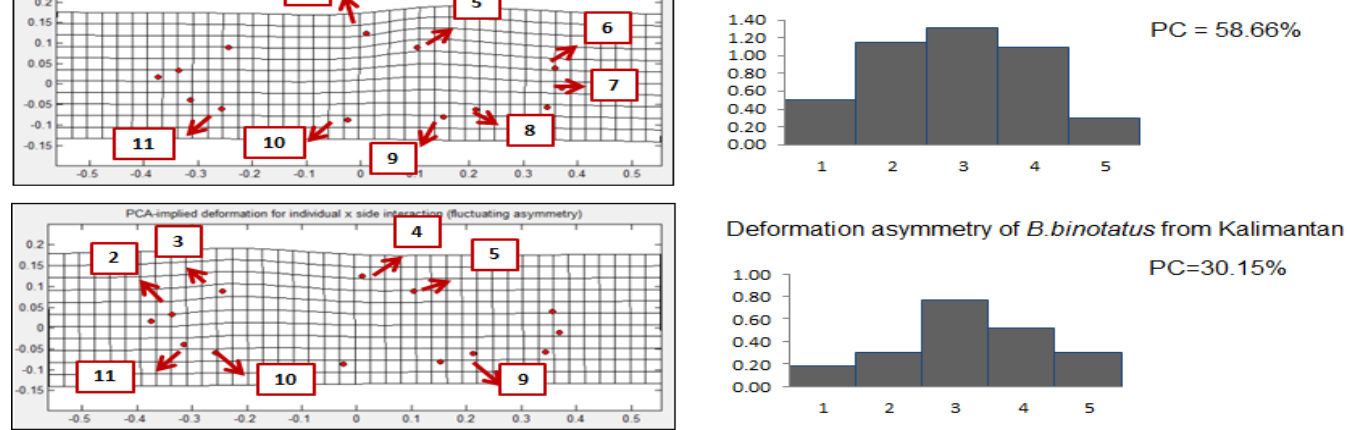

FIGURE 3. Affected landmark of B. binotatus perfected with fluctuating asymmetry

\section{CONCLUSION}

The results showed that B. binotatus from Java, Bali, Sumatra, and Nusa Tenggara had a higher percentage of FA. This means that there is an abnormality in the shape of the body (asymmetric deviation) which causes a large asymmetry value, possibly influenced by internal and external factors that are more complex than other populations. External factors that can affect the high level of asymmetry are probably due to environmental pressure or river pollution and differences in habitat conditions. The value of the fluctuating asymmetry arises due to the instability of individual development. This developmental instability affects morphometric variations in organisms, causing a higher level of asymmetry value. This perspective can be inferred through the asymmetric pattern of this morphometric character from the asymmetric deformation in the geometric-morphometric analysis. Other results indicate that the level of asymmetry of $B$. binotatus from Kalimantan and Sulawesi is lower than other populations. This is presumably due to the influence of different environmental pressures received by a population to survive in different habitats. Other analyzes concluded 
that geographic differences contribute to different environmental pressures on populations and influence the developmental instability of organisms. Morphometric variations and FA levels that occur in the population-based on each comparison from various locations may also be influenced by inbreeding activity due to the low genetic diversity in the population. Therefore, further research with genetic approaches and environmental studies is needed to find out more deeply and prove the role of genetics, inbreeding activity and habitat pressure on the level of asymmetry in the body shape of $B$. binotatus.

\section{ACKNOWLEDGEMENTS}

The authors wish to thank the Ministry of Research and Technology through PMDSU research granted for financial support for the year of 2019 granted through Faculty of Fisheries and Marine Science, University of Brawijaya, Malang, Indonesia.

\section{REFERENCES}

Almeida, D., Almodovar, A., Nicola, G.G. \& Elvira, B. 2008. Fluctuating asymmetry, abnormalities and parasitism as indicators of environmental stress in cultured stocks of goldfish and carp. Aquaculture 279(1-4): 120-125.

Astuti, S.S., Hariati, A.M., Kusuma, W.E. \& Wiadnya, D.G.R. 2020. Morphometric asymmetry of Barbodes binotatus (cyprinidae) collected from three different rivers in Java. IOP Conference Series: Earth and Environmental Science 441: 1-6.

Baumgartner, L. 2005. Fish in Irrigation Supply Offtakes- A Literature Review. 11th ed. Australia: NSW Department of Primary Industries. pp. 1-22.

Bergstrom, C.A. \& Reimchen, T.E. 2005. Habitat dependent associations between parasitism and fluctuating asymmetry among endemic stickleback populations. Journal of Evolutionary Biology 18(4): 939-948.

Bergstrom, C.A. \& Reimchen, T.E. 2003. Asymmetry in structural defenses: Insights into selective predation in the wild. Evolution 57(9): 2128-2138.

Bergstrom, C.A. \& Reimchen, T.E. 2002. Geographical variation in asymmetry in Gasterosteus aculeatus. Biological Journal of the Linnean Society 77(1): 9-22.

Bonada, N. \& Williams, D.D. 2002. Exploration of utility of fluctuating asymmetry as an indicator of river condition using larvae of caddisfly Hydropsychemorosa (Trichoptera: Hydropsychidae). Hydrobiologia 481: 147-156.

Cabuga, C.C., Apostado, R.R.Q., Abelada, J.J.Z., Calagui, L.B., Presilda, C.J.R., Angco, M.K.A., Bual, J.L., Lador, J.E.O., Jumawan, J.H., Jumawan, J.C., Havana, H.C., Requieron, E.A. \& Torres, M.A.J. 2017. Comparative fluctuating asymmetry of spotted barb (Puntius binotatus) sampled from Rivers of Wawa and Tubay, Mindanao, Philippines. Computational Ecology and Software 7(1): 8-27.
Cadrin, S.X. 2000. Advances in morphometric identification of fishery stocks. Reviews in Fish Biology and Fisheries 10: 91-112.

Daloso, D.M. 2014. The ecological context of bilateral symmetry of organ and organisms. Natural Science 6(4): 184-190.

Dar, S.A., Najar, A.M., Balkhi, M.H., Rather, M.A. \& Sharma, R. 2012. Length weight relation- ship and relative condition factor of Schizopyge esocinus (Heckel, 1838) from Jhelum River, Kashmir. International Journal of Aquatic Science 3(1): 29-36.

Dorado, E., Torres, M.A.J. \& Demayo, C. 2012. Describing body shapes of the white goby, Glossogobius giuris of Lake Buluan in Mindanao, Philippines using landmark-based geometric morphometric analysis. International Research Journal of Biological Sciences 1(7): 33-37.

Ducos, M.B. \& Tabugo, S.R.M. 2015. Fluctuating asymmetry as bioindicator of stress and developmental instability in Gafrarium tumidum (rib bed venus clam) from coastal areas of Iligan Bay, Mindanao, Philippines. Aquaculture, Aquarium, Conservation \& Legaslation International Journal of the Bioflux Society 8(3): 292-300.

Farinordin, F.A., Nilam, W.S.W., Husn, S.H., Samat, A. \& Nor, S.M. 2017. Scale morphologies of freshwater fishes at Tembat Forest Reserve, Terengganu, Malaysia. Sains Malaysiana 46(9): 1429-1439.

Fessehaye, Y., Komen, H., Rezk, M.A., van Arendonk, J.A.M. \& Bovenhuis, H. 2007. Effects of inbreeding on survival, body weight and fluctuating asymmetry (FA) in Nile tilapia, Oreochromis niloticus. Aquaculture 264(1-4): 27-35.

Hata, H., Yasugi, M., Takeuchi, Y., Takashi, S. \& Hori, M. 2013. Measuring and evaluating morphological asymmetry in fish: Distinct lateral dimorphism in the jaws of scale-eating cichlids. Ecology and Evolutions 3(14): 4641-4647.

Hendry, A.P., Bohlin, T., Jonsson, B. \& Berg, O. 2003. To sea or not to sea? Anadromy versus non-anadromy in salmonids. In Evolution Illuminated: Salmon and Their Relatives. New York: Oxford University Press. pp. 92-125.

Hermita, J.M., Gorospe, J.G., Torres, M.A.J., Lumasag, G.J. \& Demayo, C.G. 2013. Fluctuating asymmetry in the body shape of the mottled spinefoot fish, Siganus fuscescens (Houttuyn, 1782) collected from different bays in Mindanao Island, Philippines. Science International (Lahore) 25(4): 857-861.

Iguchi, K.I., Watanabe, K. \& Nishida, M. 2005. Validity of fluctuating asymmetry as a gauge of genetic stress in ayu stocks. Fisheries Science 71: 308-313.

Iwamoto, K., Chang, C.W., Takemura, A. \& Imai, H. 2012. Genetically structured population and demographic history of the goldlined spinefoot Siganus suttatus in the northwestern Pacific. Fisheries Science 78: 249-257.

Jenkins, A., Kullander, F.F. \& Tan, H.H. 2015. Barbodes binotatus. The IUCN Red List of Threatened Species.

Johnson, O., Neely, K. \& Waples, R. 2004. Lopsided fish of the snake river basin -fluctuating asymmetry as a way of assessing impact of hatchery supplementation in chinook salmon Oncorhynchus tshawytscha. Environmental Biology and Fisheries 69: 379-393. 
Jumawan, J.H., Requieron, E.A., Torres, M.A.J., Velasco, J.P.B., Cabuga, C.C., Joseph, C.C.D., Lador, J.E.O., Cruz, H.D.D., Moreno, M.P., Dalugdugan, R.O. \& Jumawan, J.C. 2016. Investigating fluctuating asymmetry in the matric characteristics off tilapia Oreochromis niloticus sampled from Cabadbaran River, Cabadbaran City, Agusan del Norte, Philippines. Aquaculture, Aquarium, Conservation \& Legislation - International Journal of the Bioflux Society 9(1): 113-121.

Kark, S. 2001. Shifts in bilateral asymmetry within a distribution range: The case of the chucar partridge. Evolution 55(10): 2088-2096.

Kark, S., Lens, L., Dongen, V.S. \& Schmidt, E. 2004. Asymmetry patterns across the distribution range. Biological Journal of the Linnean Society 81(3): 313-324.

Kocour, M., Linhart, O. \& Vandeputte, M. 2007. Mouth and fin deformities in common carp: Is there a genetic basis? Aquaculture 272: 419-422.

Kottelat, M. 2013. The fishes of the inland waters of Southeast Asia: A catalogue and core bibliography of the fishes known to occur in freshwaters, mangroves and estuaries. Raffles Bulletin of Zoology 27: 1-663.

Kihslinger, R.L. \& Nevitt, G.A. 2006. Early rearing environment impacts cerebellar growth in juvenile salmon. Journal of Experimental Biology 209(3): 504-509.

Langerhans, R.B. \& Reznick, D. 2010. Ecology and evolution of swimming performance in fishes: Predicting evolution with biomechanics. Fish Locomotion an Etho-Ecological Perspect 200: 200-248.

Leamy, L.J. \& Klingenberg, C.P. 2005. The genetics and evolution of fluctuating asymmetry. Annual Review of Ecology, Evolution, and Systematics 36: 1-21.

Lecera, J.M.I., Pundung, N.A.C., Banisil, M.A., Flamiano, R.S., Torres, M.A., Belonio, C.L. \& Requieron, E.A. 2015. Fluctuating asymmetry analysis of trimac Amphilophus trimaculatus as indicator of the current ecological health condition of Lake Sebu, South Cotabato, Philippines. Aquaculture, Aquarium, Conservation \& Legislation International Journal of the Bioflux Society Bioflux 8(4): 507-516.

Lim, L.S., Chor, W.K., Tuzan, A.D., Malitam, L., Gondipon, R. \& Ransangan, J. 2013. Lengthweight relationships of the pond-cultured spotted barb (Puntius binotatus). International Research Journal of Biological Sciences 2(7): 61-63.

Lutterschmidt, W.I., Martin, S.L. \& Schaefer, J.F. 2016. Fluctuating asymmetry in two common freshwater fishes as a biological indicator of urbanization and environmental stress within the Middle Chattahoochee Watershed. Symmetry 8(11): 1-17.

Marquez, E. 2007. Sage: Symmetry and Asymmetry in Geometric Data Version 1.05 (compiled 09/17/08). http://www.personal. umich.edu/ emarquez/morph/. Accessed on 5 May 2020.

Isa, M.M., Rawi, C.S.M., Rosla, R., Shah, S.A.M. \& Shah, A.S.R.M. 2010. Length-weight relationships of freshwater fish species in Kerian River Basin and Pedu Lake. Research Journal of Fisheries and Hydrobiology 5(1): 1-8.
Mazzi, D., Largiader, C.R. \& Bakker, T.C.M. 2002. Inbreeding and developmental stability in three-spined sticklebacks (Gasterosteus aculeatus L.). Heredity 89: 293-299.

McKinnon, J.S., Mori, S., Blackman, B.K., David, L., Kingsley, D.M., Jamieson, L., Chou, J. \& Schluter, D. 2004. Evidence for ecology's role in speciation. Nature 429: 294-298.

Muallil, R.N., Basiao, Z.U., Abella, T.A. \& Garcia, L.M.B. 2014. Fluctuating asymmetry in genetically improved Nile Tilapia, Oreochromis niloticus (Linnaeus), strains in the Philippines. Philippine Science Letters 7(2): 420-427.

Natividad, E.M.C., Dalundong, A.O., Ecot, J., Jumawan, J.H., Torres, M.A.J. \& Requieron, E.A. 2015. Fluctuating asymmetry as bioindicator of ecological condition in the body shapes of Glossogobius celebius from Lake Sebu, South Cotabato, Philippines. Aquaculture, Aquarium, Conservation \& Legislation International Journal of the Bioflux Society Bioflux 8(3): 323-331.

Pana, B.H.C., Lasutan, L.G.C., Sabid, J.M., Torres, M.A.J. \& Requiron, E.A. 2015. Using geometric morphometrics to study the population structure of the silver perch, Leiopotherapon plumbeus, from Lake Sebu, South Cotabato, Philippines. Aquaculture, Aquarium, Conservation \& Legislation International Journal of the Bioflux Society 8(3): 352-361.

Poulet, N., Reyjol, Y., Collier, H. \& Lek, S. 2005. Does fish scale morphology allow the identification of populations at a local scale? A case study for rostrum dace Leuciscus leuciscus burdigalensis in River Viaur (SW France). Aquatic Sciences 67: 122-127.

Polly, D. 2019. Geometric morphometrics. In The Encyclopedia of Archaeological Sciences, edited by Varela, S.L.L. Chichester, West Sussex: Wiley Blackwell.

Presilda, C.J.R., Angco, M.K.A., Obenza, O.L.P., Membrillos, W., Vera, C.N.M. \& Requieron, I.A. 2016. Fluctuating asymmetry employed in analyzing developmental instability of Cheilopogon pinnatibarbatus from Cabadbaran City, Agusan del Norte, Philippines. Aquaculture, Aquarium, Conservation \& Legislation International Journal of the Bioflux Society 9(1): 91-99.

Robinson, B.W. \& Parsons, K.J. 2002. Changing times, spaces, and faces: Tests and implications of adaptive morphological plasticity in the fishes of northern postglacial lakes. Canadian Journal of Fisheries and Aquatic Sciences 59(11): 1819-1833.

Rohlf, F.J. 2004. Tpsdig: Digitize Landmarks and Outlines, Version 2.0.5. New York: Department of Ecology and Evolution, State University of New York.

Savriama, Y., Gomez, J.M., Perfectti, F. \& Klingenberg, C.P. 2012. Geometric morphometrics of corolla shape: Dissecting components of symmetric and asymmetric variation in Erysimum mediohispanicum (Brassicaceae). New Phytologist 196(3): 945-954

Seixas, L.B., Santos, A.F.G.N. \& Santos, L.N. 2016. Fluctuating asymmetry: A tool for impact assessment on fish populations in a tropical polluted bay. Ecological Indicators 71: 522532. 
Sotola, V.A., Ruppel, D.S., Bonner, T.H., Nice, C.C. \& Martin, N.H. 2019. Asymmetric introgression between fishes in the Red River basin of Texas is associated with variation in water quality. Ecology and Evolution 9(4): 213-226.

Swaddle, J.P. 2003. Fluctuating asymmetry, animal behavior and evolution. Advances in the Study of Behavior 32: 169-205.

Swain, D.P., Hutchings, J.A. \& Foote, C.J. 2005. Environmental and genetic influences on stock identification characters. In Stock Identification Methods, edited by Cadrin, S.X., Friedland, K.D. \& Waldman, J.R. Massachusetts: Academic Press. pp. 45-85.

Trono, D.J.V., Dacar, I.R., Quinones, L. \& Tabugo, Q.S.R. 2015. Fluctuating asymmetry and developmental instability in Protoreaster nodosus (chocolate chip sea star) as a biomarker for environmental stress. Computational Ecology and Software 5(2): 119-129.

Wedekind, C. \& Muller, R. 2004. Parental characteristics versus egg survival: Towards an improved genetic management in the supportive breeding of lake whitefish. Annales Zoologici Fennici 41(1):105-115.

Zakeyudin, M.S., Isa, M.M., Rawi, C.S.M. \& Shah, A.S.M. 2012. Assessment of suitability of Kerian River tributaries using length-weight relationship and relative condition factor of six freshwater fish species. Journal of Environment and Earth Science 2: 52-60.
Septiana Sri Astuti

Faculty of Fisheries and Marine Science

University of Brawijaya

Jl. Veteran 65145

Malang, East Java

Indonesia

Anik Martinah Hariati \& Wahyu Endra Kusuma

Department of Aquaculture

Faculty of Fisheries and Marine Science

University of Brawijaya

J1. Veteran 65145

Malang, East Java

Indonesia

Dewa Gede Raka Wiadnya*

Ichthyofauna

Faculty of Fisheries and Marine Science

University of Brawijaya

J1. Veteran 65145

Malang, East Java

Indonesia

*Corresponding author; email: dgr_wiadnya@ub.ac.id

Received: 5 October 2020

Accepted: 16 May 2021 